\title{
Spinal cavernous haemangioma causing spastic paraparesis
}

\author{
Navid Valizadeh, ${ }^{1}$ Peter McCarthy, ${ }^{2}$ John M Lynch ${ }^{1}$
}

${ }^{1}$ Department of Neurology, University Hospital Galway, Galway, Ireland 2Department of Radiology, University Hospital Galway, Galway, Ireland

\section{Correspondence to}

Dr John Lynch,

john.lynch@hse.ie
CrossMark

To cite: Valizadeh $\mathrm{N}$, McCarthy P, Lynch JM. BMJ Case Rep Published online: [please include Day Month Year] doi:10.1136/bcr-2013200679

\section{DESCRIPTION}

A 66-year-old woman presented with a 9-month history of increasing difficulty in walking. Examination revealed asymmetric spastic paraparesis and a pyramidal pattern of weakness: Medical Research Council grade 4 on the left and $4+$ on the right lower limb. Knee and ankle reflexes were symmetrical and pathologically brisk. Ankle proprioception was impaired and there was a suspended sensory level to pin-prick testing at T6/7. Examination was otherwise normal.

MRI revealed an intensely enhancing bony and soft tissue lesion arising in the body and the neural arch of T7 (figure 1) with a large extradural soft tissue component significantly compressing the spinal cord (figure 2).

The lesion was excised. A laminectomy was performed at $\mathrm{T} 6$ and $\mathrm{T} 7$, and the vertebrae from T4 to T8 were stabilised with a spinal rod. Histology of the mass confirmed a diagnosis of cavernous haemangioma.

Vertebral haemangiomas are benign vascular tumours. They are present in up to $12 \%$ of the population at autopsy and represent $3 \%$ of all spinal tumours. Most are asymptomatic and are incidental findings on imaging. Only $0.9-1.2 \%$

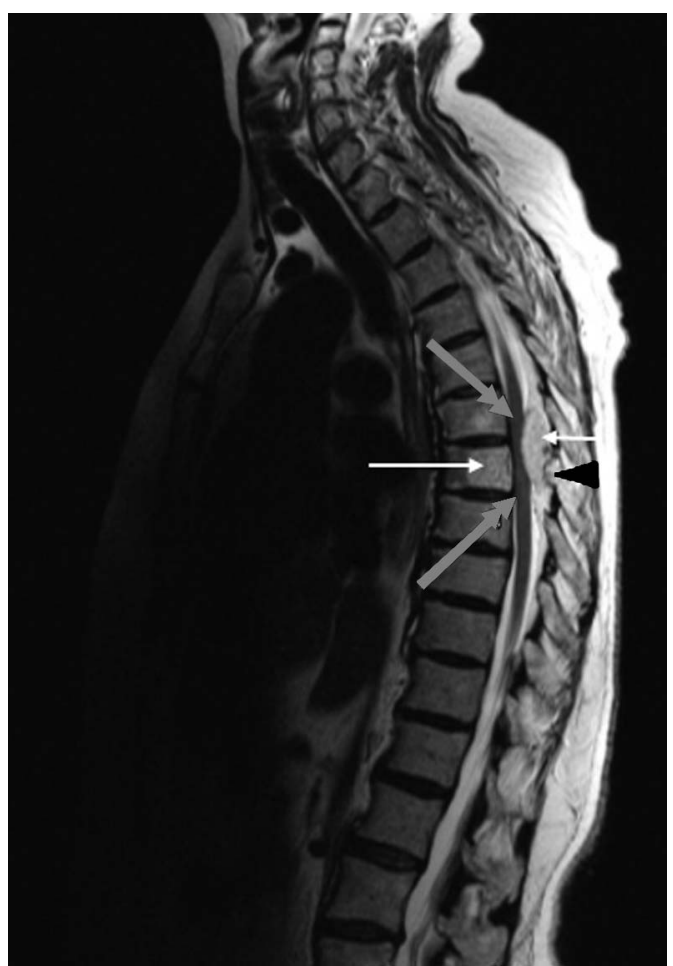

Figure 1 A sagittal T2 weighted scan shows an extradural mass (white short arrow) arising in the vertebral body (white long arrow) and neural arch (black arrowhead) of T7 and compressing the spinal cord (grey long arrows).

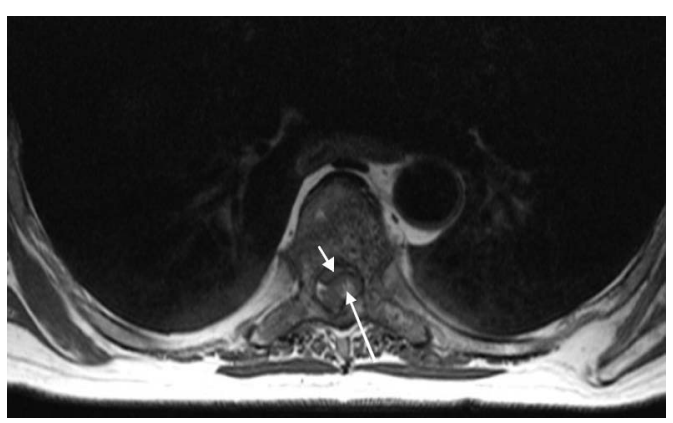

Figure 2 An axial gadolinium-enhanced T1-weighted MR image at the level of $\mathrm{T7}$, showing the intense vascular enhancement of the extradural haemangioma component (long arrow) that compresses the spinal cord (short arrow).

cause symptoms. When presented, the symptoms typically involve vertebral pain or progressive neurological deficit. ${ }^{1}$ Surgical treatment is necessary in cases of cord compression.

Our patient had an uneventful postoperative period. Three months postoperatively she had a significantly improved sensory and motor examination.

\section{Learning points}

- This case provides an illustrative example of the radiological findings in spinal cavernous hemangioma. Two planes provide a textbook example of the various imaging features of this lesion.

- The text outlines the typical history and examination findings of a cord lesion, assisting in localisation and therefore targeting imaging. The text also provides some key statistics involving cavernous hemangiomas.

- The three month post operative follow up allows us to demonstrate the potential recovery achievable after appropriate surgical referral and intervention.

Contributors NV reviewed the case and the images, and wrote the case report with assistance and input from JML. NV also reviewed the pertinent literature concerning the case. JML cared for the patient. PMC reviewed the clinical images and provided expert interpretation.

Competing interests None.

Patient consent Obtained.

Provenance and peer review Not commissioned; externally peer reviewed.

\section{REFERENCE}

1 Pastushyn Al, Slin'ko El, Mirzoyeva GM. Vertebral hemangiomas: diagnosis, management, natural history and clinicopathological correlates in 86 patients. Surg Neurol 1998:50:535-47. 
Copyright 2013 BMJ Publishing Group. All rights reserved. For permission to reuse any of this content visit http://group.bmj.com/group/rights-licensing/permissions.

BMJ Case Report Fellows may re-use this article for personal use and teaching without any further permission.

Become a Fellow of BMJ Case Reports today and you can:

- Submit as many cases as you like

- Enjoy fast sympathetic peer review and rapid publication of accepted articles

- Access all the published articles

- Re-use any of the published material for personal use and teaching without further permission

For information on Institutional Fellowships contact consortiasales@bmjgroup.com

Visit casereports.bmj.com for more articles like this and to become a Fellow 